〔79〕ロールによる高分子の崩壊

(1958 年 12 月 17 日受理)

後滕邦夫* ・ 滕井栄麿**

雲英恒雄 ${ }^{* *}$. 小出 正樹**

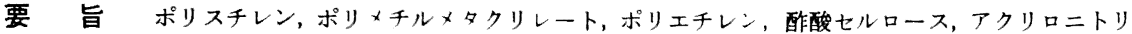
ルー醏化ビニル共重合体を熱ロールでそれぞれ素練りし，ロールの機械的な力による C-C 鎖の“ひきちぎり” がポリマーの種顛によりどのように異なるかについて，ポリマーの分子量，拉よび素練り温度を変化させて実 験した。そしてその結果，C-C 鎖の“ひきちきり”による分裂はポリマーの種類に関保し，ポリ塩化ビニル， ポリスチレン,ポリメチルメタクリレートの順に著しくなることを見出した。
\end{abstract}

\section{1. 踷言}

素練りによる高分子鎖の分裂に関しては，ゴムについ て古くから知られているところであるが", 著者らはポ リ塩化ビニルを熱ロールで素練りする祭にも C-C 鎖の 同様な分裂のあることを明らかにした2。。そしてこのよ らな C-C 鎖の分裂は高分子がロール間隙を通過すると きの塑性変形により，分子間に生ずるせん断力に応じて より短い2 個の連鎖に切断されるためであると説明され ている ${ }^{1), 8}$ 。すなわち高分子間に生ずる friction が C-C 結合力より大き: 場台にはこの結合が切れて高分子は分 裂するこレになるであろう。したがって高分子鎖のこの ような分裂においててはロール間隍の狭いとき，回転比の 大きいとき，温度の低いとき，分子鎖の長いときなど激 しく起る ${ }^{3)}$ 。この種の分裂で最終的に得られる鎖長 Plは これらの条件で生ずる frictionに対応するものであると 考えられる。またそのために，より長、鎖の分裂により 生じた $P l$ 以下の短い分子, ある: 性陚中にあらかじ め含まれていた $P l$ 以下の分子鎖には分裂がないと考え てよ(い)。

著者らはここにポリスチレン，ポリメチルメタクリレ 一ト,ポリエチレン, 酢酸セルロース,アクリロニトリ ルー塩化ビニル共重合体を熱ロールで素練りし， [r]（溶 液粘度)を追跡して,それぞれの物質を単独で素練りした とき物質の種類により分裂の模様がどのようであるかを 調べた。なお本報は後報ら以下で明らかにするようにポ リマーブレンドについての知見を得る目的も持ってい る。

\section{2. 実験}

2.1 試 料

使用したポリマー試料はそれぞれ次のようなものであ る。

ポリスチレン(Dow Chem. Co., 平均重合度 $\tilde{P}=2000)$,

* 大阪工業大学応用化学科 (大阪市旭区大宫北町 1)

** 要知県工業指道所化学部(名古屋市千種区花田町 3 の 58 )
ポリメチルメタクリレートA（三菱レイヨン $\mathrm{KK}, \bar{P}=$ $2200)$, 同 B $(P=1000)$, ポリェチレンA（三井化学 $\mathrm{KK}$, Hizex), 同 B (UCC, DYNH, $\tilde{P}=1000)$, 酶酸七ルロース (大日七ル KK, 成型用コンパウンド $\bar{M}=60000$ ), アク リロニトリルー塩化ピニル共重合体 (鐘淵化学 $\mathrm{KK}$, 共重 合組成 $40: 60,[r]_{\text {cyclohexanone }} 30^{\circ} \mathrm{C}=0.945 \mathrm{~d} / / \mathrm{g}$ )

\section{2 素練り}

著者らが先にポリ塩化ビニルについて行なったと同じ 方法2)を用いた。すなわち試料 $100 \mathrm{~g}$ を 6 in $\times 12$ in の 2 本ロールで素練りし，所定時間ごとに試料の一部を切 り取り,それの溶液粘度を測定して $P=K[\gamma]^{\alpha} に よ り$ 重 合度 $P$ を求めて分裂の模様を調べた。ロールの間隙 $(0.5$ $\mathrm{mm})$, 回転比 (17:19 rpm) は一定としてロール温度を $120 \sim 160^{\circ} \mathrm{C}$ で行なった。

\section{3 粘度測定および重合度算出}

オストワルド粘度計を使用して常法に従って行なっ た。溶媒ならびに温度はポリェチレンにはキシレンの $80 \pm 0.1^{\circ} \mathrm{C}$, 酢酸七ルロースには了セトンの $25 \pm 0.01^{\circ} \mathrm{C}$, その他にはシクロへキサノンの $30 \pm 0.02^{\circ} \mathrm{C}$ をそれぞれ 使用した。なおポリスチレン，ポリメチルメタクリレー トのシクロへキサノン溶液についての $[r]-P$ 関係式は心 ンゼンに関して文献に記载されているものから第1図を 作四して求めた。シクロへキサノンを使用したのは実験

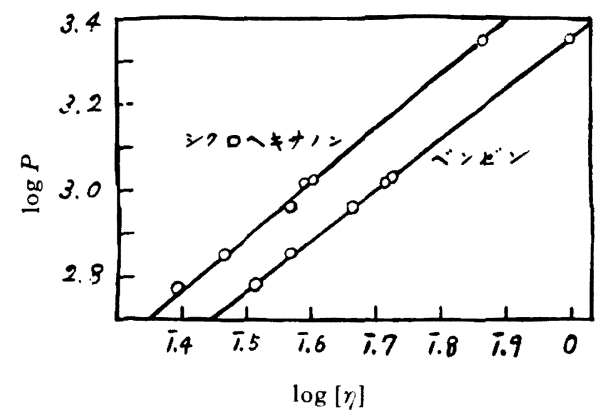

第 1 図 ポリメチルメタクリレートの $\log [\eta]-\log P$ 
第 1 表 ポリスチレンの $[\eta]$ と重合度 $\left(30^{\circ} \mathrm{C}\right)$

\begin{tabular}{|c|c|c|c|}
\hline \multirow{2}{*}{$\frac{\text { 心 }}{\left[r_{j}\right]}$} & \multirow{2}{*}{$\begin{array}{l}\text { 冫 } \\
P\end{array}$} & \multicolumn{2}{|c|}{ シクロヘキサノン } \\
\hline & & {$[\gamma]$} & $P$ \\
\hline 1.116 & 2005 & 0.922 & 2005 \\
\hline 0.722 & 1221 & 0.616 & 1222 \\
\hline 0.604 & 996 & 0.522 & 995 \\
\hline
\end{tabular}

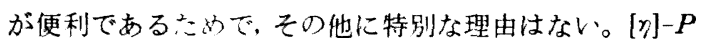
関係式はそれぞれ下記を用いた。

$$
\begin{aligned}
& \text { ポリスチレン }
\end{aligned}
$$

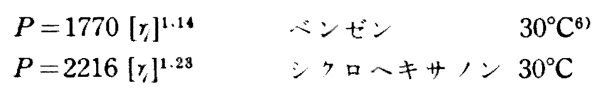

\section{3. 結果}

\section{1 ポリスチレン}

同一試料を異なる温度 $140 \sim 160^{\circ} \mathrm{C}$ で素練りし，ポリ スチレンの主鎖分裂に及ぼす温度効果を謂べたが，その 結果を第 2 図に示す。素練り温度が低いと重合度低下は

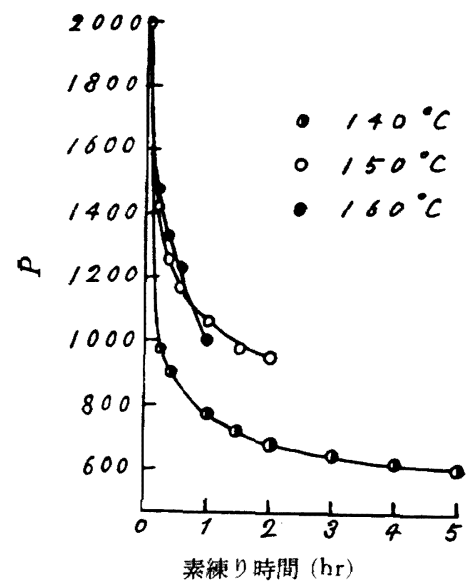

第2図ポリスチレンの素練り

激しく，また終局の重合度も小さい。高温で行ならとき は激しいモノマー臭があって解重合が起っていると考え

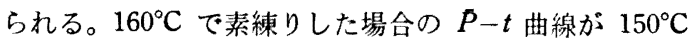
の場合の曲線と交錯しているのはこの理由によるもので

\begin{tabular}{|c|c|c|c|}
\hline $\begin{array}{l}\text { 時 間 } \\
(\min )\end{array}$ & ポリスチレン & 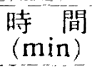 & $\begin{array}{l}\text { ポメチルメ } \\
\text { タタレー1 }\end{array}$ \\
\hline 0 & 0.406 & 0 & 0.388 \\
\hline 30 & 0.447 & 120 & 0.475 \\
\hline 120 & 0.449 & 300 & 0.706 \\
\hline
\end{tabular}
あろう。第 2 表には $150^{\circ} \mathrm{C}$ で素練りしたポリスチレン

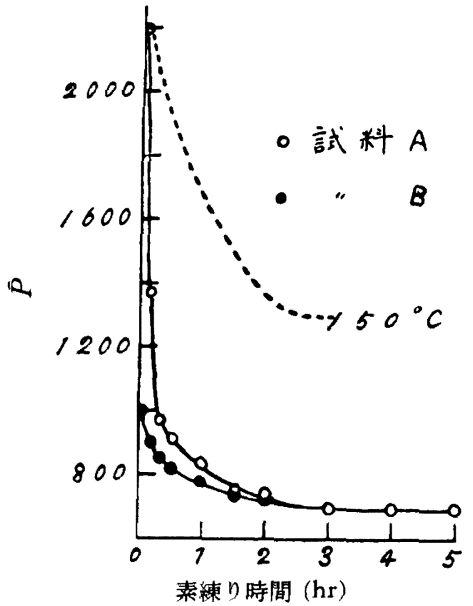

\begin{tabular}{|c|c|c|c|c|}
\hline 時 & 間 $(\min )$ & {$[\eta]_{80^{\circ} \mathrm{C}}$} & 備 & 考 \\
\hline & 0 & - & \multicolumn{2}{|c|}{$80^{\circ} \mathrm{C}$ でキシレンに不溶 } \\
\hline & 30 & - & \multicolumn{2}{|c|}{$" \prime$} \\
\hline & 60 & - & \multicolumn{2}{|c|}{$" \prime$} \\
\hline & 120 & 0.9083 & \multirow{3}{*}{\multicolumn{2}{|c|}{$\begin{array}{l}\text { 白 濁 } \\
\text { 溶 解 }\end{array}$}} \\
\hline & 180 & 0.7321 & & \\
\hline & 300 & 0.3843 & & \\
\hline
\end{tabular}

第 3 図ポリメチルメタクリレートの素練り（点線 はポリ壏化ビニルの結果 ${ }^{2}$ )

の $k^{\prime}$ を示すが， $k^{\prime}$ には素練りしたことによる大きな変 化は認められない。

第 2 表 素練りによる $k^{\prime}$ の変化

第 3 表 低圧法ポリエチレンの素練り

3.2 ポリメチルメタクリレート

重合度異なる 2 種の試料を同一温度で素練りした結果 を第 3 図に示すが, 初期重合度大なるものに激しい低下 がみられる。しかし到達する最終重合度においては $\mathrm{A}$, Bいずれの試料についても同一值を与える。ポリメチル メタクリレートでは前記ポリスチレンに比べて第 2 表に 示すように素練りにより $k^{\prime}$ が増加する。

\section{3 ポリエチレン}

重合法の異なる試料について行なったが，試料Aでは $150^{\circ} \mathrm{C}$ で，Bは $120^{\circ} \mathrm{C}$ でそれぞれ絜練りした。素練りし ないA $80^{\circ} \mathrm{C}$ のキシレンに完全に溶解しないが，第 3 表に示すよらに素練りを続けることにより 2 時間以後可 


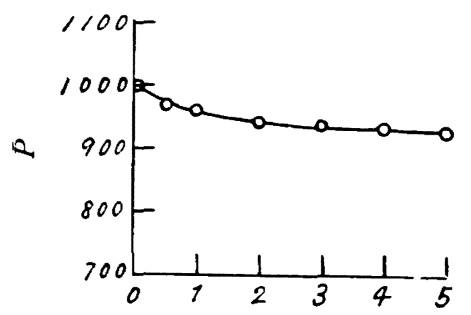

素練门時間 ( $\mathrm{hr}$ )

第4図 ポリエチレンBの素練り $\left(120^{\circ} \mathrm{C}\right)$

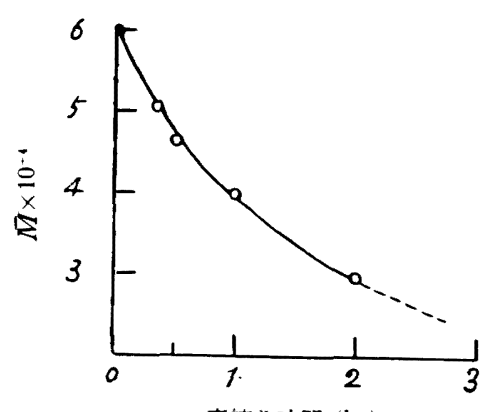

素練り時間 $(\mathrm{hr})$

第5図酢酸七ルロースの素練り $\left(150^{\circ} \mathrm{C}\right)$

素練り時間 $(\mathrm{hr})$

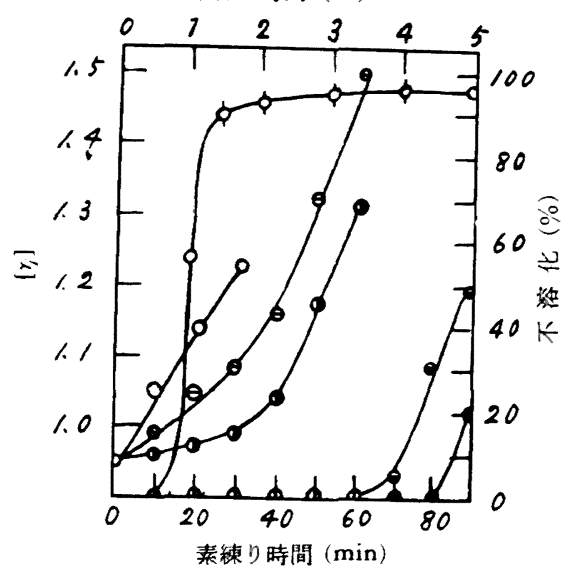

$[\eta]: \bigcirc$ 添加物なし， $\ominus$ ハイドロキノン 3 部

無水マレイン酸 3 部

不溶化: 仓添加物なし，○ハイドロキノン

なお $○$ の横軸は上の目盛である

第 6 図アクリロニトリルー塩化ビニル 共重合体の素練り $\left(150^{\circ} \mathrm{C}\right)$

溶となり, 重合度測定も可能となった。しかし 5 時間後 においても一定重合度に達する様子はみられない。一方 Bの素練りはこの試料の流動性が $150^{\circ} \mathrm{C}$ で大きいために

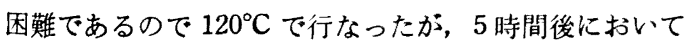
もその重合度はわずかに100しか低下しなかった。ポリ
エチレンは特に酸化されやすいので(0)この程度の重合度 低下を C-C 鎖の “ひきちぎり”のみによるものである 上断定することはできない。

\section{4 酢酸セルロース}

酢酸セルロースは $150^{\circ} \mathrm{C}$ で素練りできないので, 可塑 剂 (DMP) 含有物について行なった。しかし素練り中可 塑剤が逸散して 105 分後には䋕練り不能となったのでう ちきった。その分裂の様子を第 5 図に示す。

\section{5 アクリロニトリル-塩化ピニル共重合体}

$150^{\circ} \mathrm{C}$ で素練りした場合の粘度, $k^{\prime}$, 不溶化量の変化 在第6 図に図示する。図から明らかなようにこのものに は粘度低下がみられず, 逆に素練りとともに粘度は增加 し 40 分以後不溶物を生じる。この不溶物はハイドロキ ノン，無水マレイン酸の添加により，その生成期をそれ ぞれ 80,65 分に遅延することができるが, 生成速度はほ とんど変わらない。また $k^{\prime}$ も素練りとともに著しく増 大する。なおこの試料は着色が著しい。

\section{4. 考察}

素練りによる高分子鎖の分裂は，ゴム1),11 およびポリ 塩化ビニル2,3)について述ベられているように, 分子鎖 の機械的な“ひきちぎり”により 2 個のより短い分子に 切断される結果であるが, ポリスチレン，ポリメチルメ タクリレート，酢酸セルロースなどに扔いても同様な分 裂が起る。一般に高分子鎖の機械的な切断ではポリマー 分子間に働く摩擦力 $f$ が C-C 結合力 $F$ との間に $f>F$ の関倸を生じるときに起ると考えられている。F は重合 度その他により変わるものではないが, $f$ はポリマーの 種類, 重合度, 温度, せん断速度などにより影響される

素練り温度の変化に対してはポリスチレンの分裂に熱 解重合を除けば低温で素練りするほど激しいという結果 を与える。低温では $f$ が大きいために短い鎖にまで分裂 する。またポリメチルメタクリレートAおよびBの分裂 にみられるように重合度大なるものが分裂しやすいが, これは $f$ が重合度に依存し $f=F$ となるような重合度 $P l$ になるまで分裂が繰り返えされることを示すものであ る。すなわち分裂の終局における重合度 $P l$ は同族ポリ マーについて温度, 加えられる外力などが同じである限 り，初期重合度とは無関倸に規定されることになる。ま た $P l$ 以下の分子鎖では $f<F$ となり切断がないと考え てよいけので，Plに到達して分裂はやむ。これらのこと はすでにポリ塩化ビニルの素練りに2),8 ついて明らかに したところであるが，本報で得られた結果もこれとなん ら矛盾するものでないと判断される。ポリェチレンでは friction が小さいために， $f \geqq F$ を満足する重合度はか なり大きいと考えられるが，結果が必らずしもこの考え を明確に支持しないのは特に酸化分裂(10)などの影響であ ろう。またポリェチレン A, B についての分裂には差異 
があるが、これは重合法による分子構造の差異が素練り に対する分子の配向性に影響する結然でもあろう。各ポ リマーについて $\bar{P}-t$ 図から外插して求めたそれぞれの条 件に対する $P l$ 值を第 4 表に一括する。前項でも述べた

第 4 表 各種ポリマーの $P l$ 値

\begin{tabular}{lrl}
\hline ポリマ & $P l$ & \begin{tabular}{c} 
条 $\left({ }^{\circ} \mathrm{C}\right)$ \\
\hline 件
\end{tabular} \\
\hline ポリ塩化ビニル1 & 1250 & 150 \\
ポリスチレン & 600 & 140 \\
ポリスチレン & 900 & 150 \\
ポリ×チルメタクリレート & 700 & 150 \\
\hline
\end{tabular}

ようにポリエチレンの $P l$ はこれを純機械的切断と断定 するには不正確であるので記载から除外した。前述のよ ラに“ひきちぎり”を受けた分子鎖は 2 個のラジカル11) に分裂するが，そのラジカルを他の化学反応 ${ }^{12)}$ に利用す る限りに扔いては, Plの小さいポリマーもしくはPlを小 さくする条件を使用するのが有利であると考えられる。

Larsen, Drikamer ${ }^{13)}$ によればポリスチレンの mechanical degradation におゔて, 生じたラジカルが、へ ンゼン核を攻撃して不溶物を生じるとあるが，著者らの 場合素練りによる不溶物の生成は認められない。また分 岐分子の生成 ${ }^{3)}$ を暗示する Huggins の $k^{\prime}$ 定数の増大 ${ }^{(4)}$ もな、。しかしポリメチルメタクリレートには $k^{\prime}$ の増 加があり，素練りによる分岐の生成3を暗示する。アク リロニトリルー塩化ビニル共重合体では素練りとともに 溶液粘度が増大し, 著しい着色上不溶物を生じるが, そ の不溶化が断片のラジカルと連鎖内の二重結合間上の反 応 ${ }^{3)}$ によるものであるか, あるいは $\mathrm{C} \equiv \mathrm{N}$ 基の環状化 ${ }^{15)}$ によるものであるかは明らかでない。しかし無水マレイ ン酸による $\mathrm{C}=\mathrm{C}$ の消去, ハイドロキノンによるラジカ ルの消滅を意図したこれらの添加が粘度の增大を抑制 し、不溶物の生成期を遅延することははなはだ興味深い。 これについては後報で述へたい。
以上各種ポリマーをロールで練り C-C 鎖の機戌的な 切断を調べたが，同一素練り条件に関する限り，どれほ どの重合度 $P l$ にまで分裂するかはポリマーの種類によ り規定されるものであり，いずれもその初期の重合度に 無関倸であって少なくもポリ塩化ビニル, ポリスチン, ポリメチルメタクリレートの順に，より短い鎖にまで分 裂することがわかった。

付 記：本報は昭和 33 年 5 月高分子学会年次大会にお いて誨演した。

\section{文献}

1) たとえば 古川淳二：化学と工業, 9, 404(1956)に 総説がある。

2) 古沢至誠, 小出正樹, 後藤邦夫：高化, 10, 263 (1953)

3) 後藤邦夫, 藤井栄魔：高化, 13, 305(1956)

4) 後藤邦夫：高化, 14, 327 (1957)

5）後藤邦夫, 雲英恒雄, 藤井栄魔, 小出正樹：高化投 稿中

6) A.V. Tobolsky: J. Am. Chem. Soc., 74, 938 (1952)

7) A.V. Tobolsky: J. Polymer Sci., 9, 171 (1952)

8) J. Harris: ibid., 8, 351 (1952)

9) A.M. Sookne and M. Harris: Ind. Eng. Chem., 37, 573(1945)

10) H.W.H. Robinson and H.A. Vodder: Ind. Eng Chem., 47, 1481 (1955)

11) W.F. Kauzman and Eyring: J. Am. Chem. Soc. 62, 3113(1936)

12) W.F. Watson and D. J. Angier: J. Polymer Sci., 20, 235(1956); ibid., 25, 1(1957)

13) H.A. Larsen and H.G. Drickamer: J. Phys. Chem., 61, 1643(1957)

14) L.H. Cragg and J.A. Manson: J. Polymer Sci., 9, 265(1952)

15) W. J. Burlant and J.L. Parsons: J. Polymer Sci., 22, 249(1956)

\title{
Mechanical Degradation of Long Chain Molecules by Roll Milling
}

\author{
By Kunio Goto*, Hidemaro Fujii**, Tsuneo Kira** and Masaki Koide**
}

\begin{abstract}
The millings of polystyrene, polymethylmethacrylate, polyethylene, cellulose acetate and acrylnitrile-vinylchloride co-polymer were carried out with heating rolls, and the mechanical degradation of these polymers was studied. The degradation of polymer would be examined by measuring the viscosity of polymer solution. It was posturated that during mastication, $\mathrm{C}-\mathrm{C}$ bonds, the back bone of polymer, were broken by the shearing force, resulting in the decrease of a chain length. No degradation appears to occure after the chain length is reached to a limitting length for a given polymer. It was found that the order in the rate of the mechanical degradation was polyvinylchloride, polystyrene, polymethylmethacrylate at our experimental condition.
\end{abstract}

* Department of Applied Chemistry, Osaka Technical College (1, Omiya Kitanomachi, Asahiku, Osaka)

** Aichi Industrial Council (3-58, Hanadacho, Chikusrku, Nagoya) 